\title{
THE INFLUENCE OF USING VISUAL PICTURE SEQUENCE TOWARDS STUDENTS' ABILITY IN WRITING PROCEDURE TEXT
}

\author{
Ledy Nurlely ${ }^{1}$, Sutrisno Sadji Evenddy ${ }^{2}$, Arlini ${ }^{3}$ \\ ${ }^{1}$ Universitas Sultan Ageng Tirtayasa \\ ${ }^{2}$ Universitas Sultan Ageng Tirtayasa \\ ${ }^{3}$ Universitas Sultan Ageng Tirtayasa \\ ledy@untirta.ac.id ${ }^{1}$,sutrisno.se@untirta.ac.id ${ }^{2}$, arlinialin19@gmail.com ${ }^{3}$
}

\begin{abstract}
This research is aimed to find out whether there is a significant influence of using Visual Picture Sequence towards students' ability in writing procedure text. This research used quantitative method and quasi experimental design, conducted by using pre-test - treatment - post test design. The instrument used in this research was test (pre-test and post-test). This research was conducted in two classes; experimental class and control class, exactly in English classroom. The population of this research was the twelfth grade of MAN 2 KOTA SERANG in academic year 2020/2021. The samples of this research were XII IPS 2 as experimental class and XII IPS 3 as control class both consisted 33 students. The experimental class was taught by using Visual Picture Sequence and the control class without using Visual Picture Sequence. The data of this research was collected by giving the writing test about procedure text in pre-test and post-test. The post test mean score of control class was 79,75 and the post-test mean score of experimental class was 84,75 . The collected data were analyzed by using t-test. The result of data analysis showed that the value of $\mathrm{t}$-count was higher than the value of $\mathrm{t}$-table $(11,2 \geq$ 2.00 ) at the level of significant of a 0.05 and degree of freedom is 64 . It means that the alternative hypothesis (Ha) was accepted and null hypothesis $\left(\mathrm{H}_{0}\right)$ was rejected. From those findings, it could be concluded that there was significant influence of using Visual Picture Sequence towards students' ability in writing procedure text.
\end{abstract}

Keywords: Procedure Text; Visual Picture Sequence; Writing Skill

\begin{abstract}
Abstrak: Penelitian ini bertujuan untuk mengetahui apakah ada pengaruh signifikan dari penggunaan Visual Picture Sequence terhadap kemampuan siswa dalam menulis teks prosedur. Penelitian ini menggunakan metode kuantitatif dengan desain kuasi eksperimen, yang dilakukan dengan menggunakan desain pre test - treatment - post test. Instrumen yang digunakan dalam penelitian ini adalah tes (pre-test dan post-test). Penelitian ini dilakukan di dua kelas; kelas eksperimen dan kelas kontrol, tepatnya di kelas bahasa Inggris. Populasi penelitian ini merupakan kelas XII MAN 2 KOTA SERANG tahun akademik 2020/2021. Sampel penelitian ini adalah XII IPS 2 sebagai kelas eksperimen dan XII IPS 3 sebagai kelas kontrol. Keduanya terdiri dari 33 siswa. Kelas eksperimen diajarkan dengan menggunakan Visual Picture Sequence dan kelas kontrol tanpa menggunakan Visual Picture Sequence. Data penelitian ini dikumpulkan dengan mengadakan tes tulis tentang teks prosedur dalam pre-test dan post-test. Skor posttest kelas kontrol adalah 79,75 dan skor rata-rata post-test kelas eksperimen adalah 84,75. Data yang dikumpulkan, dianalisis dengan menggunakan $t$-test. Hasil analisis data menunjukkan bahwa nilai $t$-count lebih tinggi dari nilai $t$-table $(11.2 \geq 2,00)$ pada tingkat signifikan dari 0,05 dan tingkat kebebasan adalah 64. Ini berarti bahwa hipotesis alternatif (Ha) diterima dan hipotesis null (H0) ditolak. Dari temuan tersebut, dapat disimpulkan bahwa ada pengaruh signifikan dari penggunaan Visual Picture Sequence terhadap kemampuan siswa dalam menulis teks prosedur.
\end{abstract}

Kata Kunci: Teks prosedur, visual picture sequence, keterampilan menulis 


\section{INTRODUCTION}

In spite of the fact that writing is very important, based on some researcher's study in English classroom Indonesian student still have difficulties to develop their writing skill. A study conducted by Sesrica, Jismulatif, \& Arifanto (2017:5-7) showed that students' writing ability was still poor. They had terrible showings in organizing sentence in logical order and reasonable in framing a decent paragraph structure. There are three problems that can inhibit the students to build up their skill in writing. They are psychological, linguistic, and cognitive problems (Bryne, 1988:4). However, the previous researche in this field are less concentrated on whether is there any influence on the usage ofvisual picture sequence towards students' ability in writing procedure text. They usually use single picture and concentrated in writing other text, such as descriptive text, narrative text, and many more. In this research, the focus is the influence of using visual picture sequence towards students' writing ability in writing procedure text.

Based on the observation in MAN 2 KOTA SERANG many students find some obstacles in writing procedure text. There are some considerations why writing is regarded as a difficult skill. Richard and Renandya (2002) mention that difficulties in writing arise not only in generating and reorganizing ideas but also in translating the ideas so that the readers can be easily able to understand about what is the writing about they also proposed that second language writer should pay attention to the higher skills of writing; they are generating and reorganizing ideas. In addition, second language writer should also pay attention to the lower skills of writing such as spelling, punctuation, word choice and so on. The problem of writing especially in writing procedure text can be solved by giving media usage, one of the media that can be used is picture. Wright (1989:2) stated the contribution of learning by picture that it can increase students' interest and motivation, develop a sense of the context of the language, and represent a specific reference point or stimulus.

This research is intended to find out students' ability and difficulties in writing procedure text by using visual picture sequence as media, whether it can influence students' skills in writing procedure text or not. Based on researcher's observation and experience when PPLK in Junior High School it was found that students still have interest with visual media in English teaching and learning activity and their writing ability was still poor. They have problems in organizing sentences and lack of vocabulary. The media was used to improve their ability in writing. Also there are external factor which is the inadequate school facilities. Therefore, the researcher did preliminary observation in MAN 2 KOTA SERANG and was found that still there are some difficulties in students' writing skill and the researcher want to find out whether the media can be influence in high school level or not.

Regarding with the explanation, the researcher conducted the research to examine the influence of using Visual Picture Sequence towards students' skills in writing procedure text in high school level precisely in MAN 2 KOTA SERANG. In this research, the technique that used is test to find whether there is any influence of student's ability to writing procedure text before and after using visual picture, and the media that is appropriate to the characteristics of the students is by using visual picture sequence because it can increase students' interest in teaching and learning process, build the students' concentrate while teaching learning process, and also can help students to enjoy the teaching and learning process.

\section{METHODS}

This study is a quasi-experimental study that has been conducted online by using Nonequivalent (Pre-Test and Post-Test) control group design because the experimental group and control group are selected without random assignment and both groups are take a pre-test and post-test but only the treatment only given in experimental group. This design could be representing as follows: 


\section{\begin{tabular}{lll} 
G1 & T1 & x T2 \\
\hline
\end{tabular}}

G2 $\mathrm{T} 1 \quad \mathrm{~T} 2$

$\mathrm{G} 1=$ experiment class

$\mathrm{G} 2=$ control class

$\mathrm{T} 1=$ pre-test

$\mathrm{T} 2=$ post-test

$\mathrm{xT} 2=$ treatment

Based on the design shows, the researcher gave the pre-test and treatment to the experimental class, and after that the students in experimental class receives post-test to measure their ability and find out whether there is a significance influence of the treatment or not. Meanwhile in a control class, the researcher gave the pre-test and treatment use singular picture.

In General, data sources of research are called population and Sample. Levy and Lemeshow (2008:11) stated that "The Population (or universe or target population) is the entire set of individuals to which findings of the survey are to be extrapolated." Moreover, Gupta and Kabe (2011:1) said that "A sample is only a finite portion of population". The population of this study was twelfth grade students of MAN 2 KOTA SERANG in academic year 2020/2021. This study uses quantitative method Nonequivalent (Pre-Test and Post-Test) control group design with the sample of this study involved a number of people in two classes at twelfth grade of MAN 2 KOTA SERANG.

The instrument that used in this study to assessing students' writing skill is an essay test as a quantitative instrument. There were pre-test and post-test. Students were asked to write a procedure text. To find out the result, the researcher need to measure students' score in writing test. There are so many way to give a score for a test. One of them is analytic score from Arthur Hughes (2003:101-102) that being chosen as a guide for this research. In Hughes theory there are some aspects which can be used to help the researcher in scoring writing test.

Table 1. Analytic Scoring of Writing

\begin{tabular}{lll}
\hline Criteria & $\begin{array}{c}\text { Rating } \\
\text { Score }\end{array}$ & \multicolumn{1}{c}{ Indicators } \\
\hline 6 & Few (if any) noticeable errors of grammar or word order. \\
5 & $\begin{array}{l}\text { Some errors of grammar or word order which do not, however, interfere with } \\
\text { comprehension. }\end{array}$ \\
4 & $\begin{array}{l}\text { Errors of grammar or word order fairly frequent, occasional re-reading } \\
\text { necessary for full comprehension. }\end{array}$ \\
& 2 & $\begin{array}{l}\text { Errors of grammar or word order frequent; efforts of interpretation sometimes } \\
\text { required on reader's part. } \\
\text { Errors of grammar or word order very frequent; reader often have to rely on } \\
\text { own interpretation. } \\
\text { Errors of grammar or word order are so severe as to make comprehension } \\
\text { virtually impossible. } \\
\text { Use of vocabulary and idiom rarely (if at all) distinguishable from that of an } \\
\text { educated native writer. } \\
\text { Occasionally uses inappropriate terms or relies on circumlocutions; expression }\end{array}$ \\
& 5 &
\end{tabular}




\begin{tabular}{|c|c|c|}
\hline & & of ideas hardly impaired. \\
\hline \multirow[t]{7}{*}{ Vocabulary } & 4 & $\begin{array}{l}\text { Uses wrong or inappropriate words fairly frequently; expression of ideas may } \\
\text { be limited because of inadequate vocabulary. }\end{array}$ \\
\hline & 3 & Limited vocabulary and frequent errors clearly hinder the expression of ideas. \\
\hline & 2 & $\begin{array}{l}\text { Vocabulary so limited and so frequently misused that reader must often rely on } \\
\text { own interpretation. }\end{array}$ \\
\hline & 1 & $\begin{array}{l}\text { Vocabulary limitations so extreme as to make comprehension virtually } \\
\text { impossible. }\end{array}$ \\
\hline & 6 & Few (if any) noticeable lapses in punctuation or spelling. \\
\hline & 5 & $\begin{array}{l}\text { Occasional lapses in punctuation or spelling which do not, however, interfere } \\
\text { with comprehension. }\end{array}$ \\
\hline & 4 & $\begin{array}{l}\text { Errors in punctuation or spelling fairly frequent; occasional re-reading } \\
\text { necessary for full comprehension. }\end{array}$ \\
\hline \multirow[t]{6}{*}{ Mechanics } & 3 & Frequent errors in spelling or punctuation, lead sometimes to obscurity. \\
\hline & 2 & $\begin{array}{l}\text { Errors in spelling or punctuation so frequent that reader must often rely on } \\
\text { own interpretation. }\end{array}$ \\
\hline & 1 & $\begin{array}{l}\text { Errors in spelling or punctuation so severe as to make comprehension virtually } \\
\text { impossible. }\end{array}$ \\
\hline & 6 & $\begin{array}{l}\text { Choice of structure and vocabulary consistently appropriate, like that of an } \\
\text { educated native writer. }\end{array}$ \\
\hline & 5 & $\begin{array}{l}\text { Occasional lack of consistency in the choice of structures and vocabulary } \\
\text { which does not, however, impair overall ease of communication. }\end{array}$ \\
\hline & 4 & $\begin{array}{l}\text { 'Patchy', with some structures or vocabulary items noticeably inappropriate to } \\
\text { general style. }\end{array}$ \\
\hline \multirow[t]{6}{*}{ Fluency } & 3 & $\begin{array}{l}\text { Structures or vocabulary items sometimes not only inappropriate but also } \\
\text { misused; little sense of ease of communication. }\end{array}$ \\
\hline & 2 & $\begin{array}{l}\text { Communication often impaired by completely inappropriate or misused } \\
\text { structures or vocabulary items. }\end{array}$ \\
\hline & 1 & $\begin{array}{l}\text { A 'hotch-potch' of half-learned misused structures and vocabulary items } \\
\text { rendering communication almost impossible. }\end{array}$ \\
\hline & 6 & $\begin{array}{l}\text { Highly organized; clear progression of ideas well linked; like an educated } \\
\text { native writer. }\end{array}$ \\
\hline & 5 & $\begin{array}{l}\text { Material well organized; links could occasionally be clearer but } \\
\text { communication not impaired. }\end{array}$ \\
\hline & 4 & Some lack of organization; re-reading required for clarification of ideas. \\
\hline \multirow[t]{3}{*}{$\begin{array}{c}\text { Form } \\
\text { (organization) }\end{array}$} & 3 & $\begin{array}{l}\text { Little or no attempt at connectivity, though the reader can deduce some } \\
\text { organization. }\end{array}$ \\
\hline & 2 & $\begin{array}{l}\text { Individual ideas may be clear, but very difficult to deduce the connection } \\
\text { between them. }\end{array}$ \\
\hline & 1 & Lack of organization so severe that communication is seriously impaired. \\
\hline
\end{tabular}

\section{Score:}

Grammar__ + voc ___ + Mech ___fluency__ + form $=(\max$. score $)$

In the end, the researcher will calculate all the score :

Achievement score $=\underline{\text { Maximum Score }} \times 100$

30

Hughes (2003:101-102)

Data collecting technique is a technique to obtain the data. The researcher use administering test to collect the data. Brown (2003:3) stated that "A test, in simple terms, is a 
method of measuring a person's ability, knowledge, or performance in a given domain." Based on the statement, can be known that test is an instrument or a set of techniques, procedures, and items that can be used to measure person's ability. Can be seen from the explanation above that the instrument that used by the researcher was tests. The researcher used administrative test; pretest- treatment- posttest design. This study used Ms. Excel as a tool to analyze data. In this research, the data obtained from pretest and post test being analyzed by using Content Validity, Inter-Rater Reliability, Normality Test, Homogeneity Test, and the last was T-Test to measure the mean of students' scores.

\section{RESULTS AND DISCUSSION}

This research was conduct on September $15^{\text {th }}$ until October $15^{\text {th }} 2020$ at MAN 2 SERANG with the students of twelfth grade as the sample. The researcher conducted the research in two classes; XII IPS 2 as experimental class and XII IPS 3 as control class, then the experimental class consists of 33 students and the control class consists of 33 students. The data were collecting in each class in four meeting; first meeting is for the pre-test, second and third meeting are for the treatment, and the last meeting for the post-test. The treatments that have been giving in both classes are different. The experimental class was given the Visual Picture Sequence as media and the control class was given a singular picture as media. The last meeting post-test was given to each class.

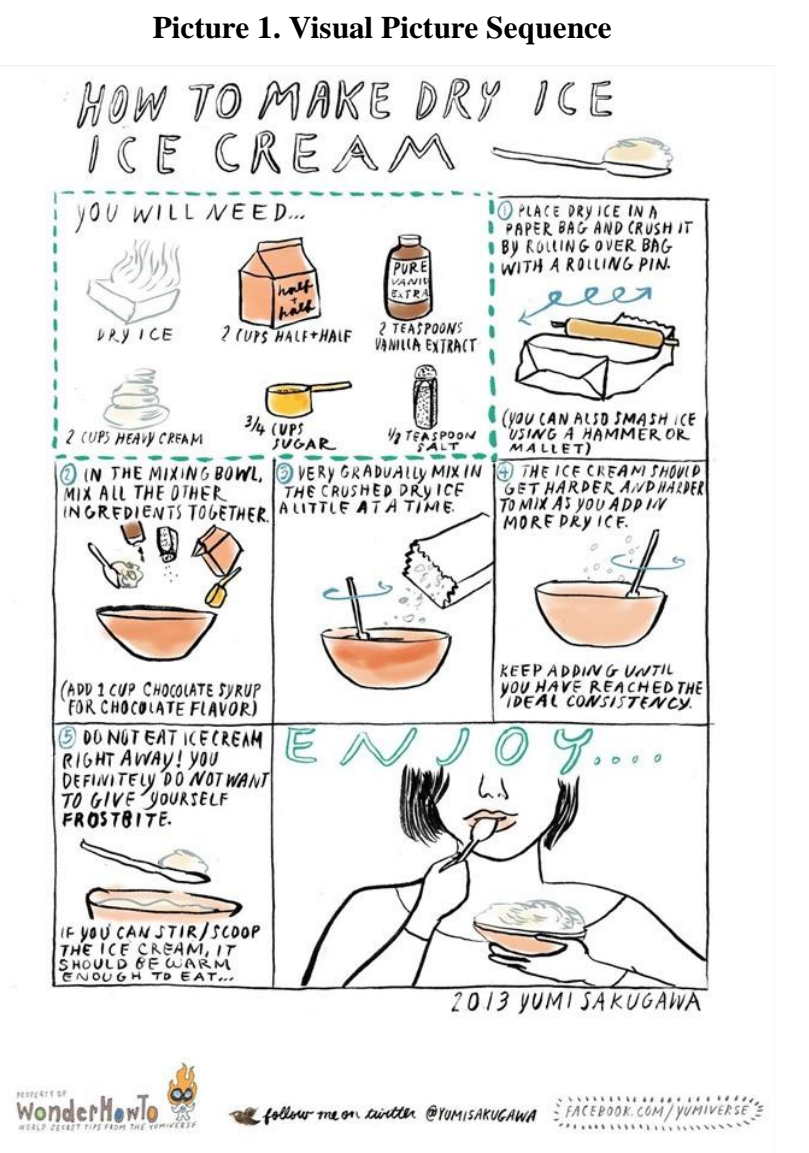

After collecting the data, the researcher calculated and analyzed it. The researcher used validity content, normality test, homogeneity test, and calculated the t-test to find out which hypothesis is accepted. 


\begin{tabular}{cccccc}
\hline & & \multicolumn{2}{c}{ Pre-Test } & \multicolumn{2}{c}{ Post-Test } \\
\cline { 3 - 5 } No. & Result & Exp & Ctr & Exp & Ctr \\
1. & Mean & 77.57 & 76.78 & 84.75 & 79.75 \\
2. & Median & 80 & 80 & 87 & 80 \\
3. & Xmax & 87 & 87 & 97 & 93 \\
4. & Xmin & 57 & 57 & 67 & 60 \\
5. & Standard Deviation & 8.41 & 7.85 & 8.88 & 8.29 \\
\hline
\end{tabular}

From the data above, it presents that there was a significant different in students' writing skill between the experimental class and control class meanwhile the experimental class was given Visual Picture Sequence as treatment and control class was not.

\section{Validity And Reliability}

Validity test used to measure the instrument of the research. In this research, the researcher use content validity. The content validity was used to measure whether the instrument was made were suitable with the curriculum (syllabus) or not. The teacher was analyzed based on content validity sheet and get that the test used was valid.

Gronlund as cited in Brown, 2004:22 said that content validity is "the extent to which inference made from assessment results are appropriate, meaningful, and useful in terms of the purpose of the assessment." The validity test is needed to make sure that the results of the test is appropriate.

After the data proved that it was valid, the research use Inter-rater reliability to see that the instrument must be reliable to avoid the ambiguousness of the content.The previous statement is supported by Creswell (2012: 161) that inter-rater reliability should be possible by two researchers and afterward they compare the scores to check whether their scores are similar or different.Thus, inter-rater reliability is a procedure that has two observers to check the reliability of the data and to compare the observation from each observer. The researcher used Cohen Kappa formula to examine the reliability. After both of raters calculated the score, the result obtained:

Table 3. Inter-Rater Reliability

$\begin{array}{cc}\text { Items } & \text { KK } \\ \text { Pre- Test of Experimental Class } & 0.68 \\ \text { Pre- Test of Control Class } & 0.61 \\ \text { Post-Test of Experimental Class } & 0.70 \\ \text { Post-Test of Control Class } & 0.69\end{array}$

The data was interpreted to find the value of coefficient agreement by seeing the kappa:

Table 4. Kappa Statistic

\begin{tabular}{cc}
\hline Kappa Statistic & Strength of agreement \\
\hline$<0.20$ & Poor \\
$0.21-0.40$ & Fair \\
$0.41-0.60$ & Moderate \\
$0.61-0.80$ & Good \\
$0.81-1.00$ & Very Good \\
\hline
\end{tabular}


Based on the table above, calculation of reliability shows that the result of the test are reliable and could be used as a research instrument because KK statistic in each class are in "good" range strange of agreement.

\section{Normality}

The normality was used in order to test whether the distribution of the test is normally distributed. This research used graphical method to measure the data normality. Hatch and Farhady (1982:64) said that the normal distribution permits the reader to conclude about the population in general and sample of the population in particular.The table of the result of normality distribution as follows:

Table 5. The Result of Homogeneity Test at Control and Experiment Class

\begin{tabular}{lrrrr}
\hline & Test & \multicolumn{3}{c}{ Result } \\
\cline { 2 - 5 } & \multicolumn{2}{c}{ Experimental } & \multicolumn{2}{c}{ Control } \\
\hline Pre- Test & $\mathrm{x}^{2}$ count $=$ & 2,10014 & $\mathrm{x}^{2}$ count $=$ & 1,60521236 \\
& $\mathrm{x}^{2}$ tabel $=$ & 11,0705 & $\mathrm{x}^{2}$ tabel $=$ & 11,07049775 \\
Post- Test & $\mathrm{x}^{2}$ count $=$ & 2,2207 & $\mathrm{x}^{2}$ count $=$ & 1,24387307 \\
& $\mathrm{x}^{2}$ tabel $=$ & 11,0705 & $\mathrm{x}^{2}$ tabel $=$ & 11,07049775 \\
\hline
\end{tabular}

If $x^{2}$ count $<x^{2}$ tabel it is means that the data was normally distributed.

\section{Homogeneity}

This research used homogeneity test to find out whether the data that have been distributed was homogenous or not. To measure the homogeneity, the researcher had to find out the homogeneity variance: $\mathrm{F}_{\text {count }}=\frac{B V}{S V}$. There are the criteria of homogeneity:

$$
\begin{aligned}
& \text { If } F_{\text {count }} \geq F_{\text {tabel }} \text { it indicates not homogenous } \\
& \text { If } F_{\text {count }} \leq \mathrm{F}_{\text {tabel }} \text { it indicates homogenous }
\end{aligned}
$$

Table 6. The Result of Homogeneity Test at Control and Experiment Class

\begin{tabular}{llll}
\hline Group & $\mathrm{F}_{\text {count }}$ Pre-test & $\mathrm{F}_{\text {count }}$ Post-test & $\mathrm{F}_{\text {table }}$ \\
\hline Control and Experiment & 0.956 & 0.849 & 1.86 \\
\hline
\end{tabular}

Pre-test $\quad: F_{\text {count }} \leq \mathrm{F}_{\text {table }} \quad=0.956 \leq 1.86$

Post-test $\quad: \mathrm{F}_{\text {count }} \leq \mathrm{F}_{\text {table }} \quad=0.849 \leq 1.86$

Based on the result of homogeneity variance of both control and experimental classes, can be concluded that the scores of pre-test and post-test in control class and experimental class was homogenous.

To prove the hypothesis of this research, statistic calculation of t-test formula with the degree of significance $5 \%$ was used. "T-test is an evaluation of the difference between two means relative to the variability in the data." (Evans and Rooney: 2008:40). The formula as follow: 


$$
t_{\text {count }}=\frac{M_{x}-M_{y}}{\sqrt{\left(\frac{\sum x^{2} \pm \sum y^{2}}{N_{x}+N_{y}-2}\right)\left(\frac{1}{N_{x}}+\frac{1}{N_{y}}\right)}}
$$

$$
\begin{aligned}
& \mathrm{M}_{\mathrm{x}} \quad \text { : Mean score of experimental group (X) } \\
& \mathrm{M}_{\mathrm{y}} \quad: \text { Mean score of control group (Y) } \\
& \sum \mathrm{x}^{2} \quad \text { : Sum of square deviation score in experimental group } \\
& \sum \mathrm{y}^{2} \quad: \text { Sum of square deviation score in control group } \\
& \mathrm{N}_{\mathrm{x}} \quad \text { : The number of students of experimental group } \\
& \mathrm{N}_{\mathrm{y}} \quad \text { : The number of students of control group } \\
& t_{\text {count }}=\frac{M_{x}-M_{y}}{\sqrt{\left(\frac{\sum x^{2} \pm \sum y^{2}}{N_{x}+N_{y}-2}\right)\left(\frac{1}{N_{x}}+\frac{1}{N_{y}}\right)}} \\
& t_{\text {count }}=\frac{85,1-78,6}{\sqrt{\left(\frac{293,052+70,41}{33+33-2}\right)\left(\frac{1}{33}+\frac{1}{33}\right)}} \\
& t_{\text {count }}=\frac{6,5}{\sqrt{\left(\frac{363,469}{64}\right)\left(\frac{2}{33}\right)}} \\
& t_{\text {count }}=\frac{6,5}{\sqrt{(5,67)(0.06)}} \\
& t_{\text {count }}=\frac{6,5}{\sqrt{0.34}}=\frac{6,5}{0,58}=11.2
\end{aligned}
$$

To find the value of $t_{\text {table }}$, the researcher used the formula as follows:

$$
\begin{aligned}
d . f & =\left(N_{x}+N_{y}-2\right) \\
& =(33+33-2) \\
& =64
\end{aligned}
$$

$t_{\text {table }}$ With the level of significance $0.05(5 \%)$ was 2.00

Step 4: Compared $t_{\text {count }}$ and $t_{\text {table }}$

The criteria of testing as follows:

If $t_{\text {count }} \geq t_{\text {table, }}$, it means that the null hypothesis $\left(H_{0}\right)$ is refused.

If $t_{\text {count }} \leq t_{\text {table, }}$ it means that the null hypothesis $\left(H_{0}\right)$ is received.

Based on the result oftest of mean difference significant (independent $t_{\text {test }}$ ), it was

Calculated $t_{\text {count }} \geq t_{\text {table }}$ or $11.2 \geq 2.00$. The alternative hypothesis was received. It can be concluded that there was an influence of using Visual Picture Sequence towards students' ability in writing procedure text.

İn this research both experimrntal and control classes were given pre-test, treatment, and post-test. The students were asked to write an essay of procedure text in pre-test and posttest. The research was conducted online during pandemic COVID-19. The online was use Google Meeting application.

In control and experimental class class there were four meeting in each class. The first meeting the researcher gave the pre-test to measure the basic knowledge of the students. From the pre-test the researcher find out the highest score in control class was 87 and in experimental was also 87, the lowest score in both class was 57 , and the mean in control was 76.78 
meanwhile in experimental class was 77,5. The data can be interprets that students' writing skill was not satisfying and the students still have a lack of writing skill.

After giving the pre-test the next process was giving a treatment to the control and experimental class. In the second meeting, the researcher gave the materials about procedure text using Singular Picture in control class and using Visual Picture Sequence in experimental class as media that being proved. The researcher introduced and gave the explanation about the materials to students, to guide them to know and increase their skill in writing especially writing procedure text.

The last meeting was post-test. The researcher gave the post-test to measure the students' score after being given the treatment. From the test the researcher find out the highest score in controll class was 93 and in experimental class was 97, the lowest score in control class was 60 and in experimental class was 67 , and the mean in control class was 79,75 meanwhile the mean in experimental class was 84.75. From the result of the post-test can be seen that the increase of score which means there are influence in using Visual Picture Sequence as treatment.

The conclusion is the students' score in experimental class was higher than the control class. It can be seen from the comparison of the highest score, lowest score, and mean between the control and experimental class. Based on the calculation of the data from control and experimental class the alternative hypothesis of the test was received it proved that there is influence of using Visual Picture Sequence towards students' ability in writing procedure text.

\section{CONCLUSIONS}

Based on the result, it can be conclude that there is a significant influence on using Visual Picture Sequence towards students' ability in writing procedure text, especially for the third year students of MAN 2 KOTA SERANG. It could be seen from score of the students' after being given the Visual Picture Sequence as treatment. The implementation of Visual Picture Sequence could help the students to organize their ideas to write procedure text correctly based on writing aspects, it also affective to increase students' interest in studying English. The students actively involved in teaching and learning process of writing procedure text.

The significant influence can be seen in the final result between the mean score of pretest and post-test. The mean score of pre-test in experimental class was 77.5 and the mean score of post-test was 84.75 , the increase was higher than the pre-test score 76.78 and post-test score 79.75 in control class.

Based on the calculation of hypothesis testing using statistical analysis with the significant level 0.05 and $\mathrm{df}=64$ the value of $t_{\text {count }}$ was 11.2 and $t_{\text {table }}$ was $2.00 . t_{\text {count }} \geq t_{\text {tabel,or }}$ $11.2 \geq 2.00$. It indicates that the $\mathrm{H}_{0}$ was rejected and the $\mathrm{H}_{\mathrm{a}}$ was accepted. There was significant influence of using Visual Picture Sequence towards students' ability in writing procedure text.

In this part, the researcher would give some suggestion based on the niche of the present research as follow; For The Researcher: The researcher can use another kind of picture or treatment to develop their own research dealing with students' writing skill, especially in writing procedure text. It is expected expected to be better than this research paper. The next researcher can use this study as a reference of media usage towards their writing mastery. For English Teacher: The English teacher can implements the Visual Picture Sequence and give the clear instruction in teaching and learning process of writing to help students understand the materials easily and increase their writing skill. The researcher also can try to another kind of picture or technique to improve students' interest in learning process of writing. For students:

Students must be enjoy in learning English especially in writing, students can use any

technique or media that can make them interest and easily understand about the materials.

\section{REFFERENCES}

Brown,H. D. 2003. Language assessment: Principles and Classroom Practices. CA: Longman. 
Byrne, D. 1988. Teaching Writing Skills. London: Longman Press.

Cresswel, J. W. 2005. Educational Research: Planning, Conducting, and Evaluating Quantitative and Qualitative Research. Merrill.

Evans, A. N., and Rooney, B. F. 2008. Methods in psychological research. US: Sage Publication Inc.

Gupta, K.A., and Kabe, D.G. 2011. Theory of Sample Surveys. Singapore: World Scientific.

Hatch, E. M., and Farhady, H. 1982. Research Design and Statistic for Applied Linguistic.CA: Newbury House.

Hughes, A. 2003. Testing for Langage Teacher. UK:Cambridge University Press.

Levy, S.P., and Lemeshow, S. 2008. Sampling of population: Method and Application. NJ: A John Wiley \& Sons, Inc., Publication.

Richard, J.C., and Renandya, W. A. 2002. Methodology in language teaching: An Anhology of current practice. NY: Cambridge University press.

Sesrica, M., Jismulatif, and Afrianto. 2017. The effect of using pictures in teaching writing descriptive text for the second year students of SMPNI SIAK HULU. Riau University, Riau 